\title{
Cytotoxicity and mutagenicity of fluoxetine hydrochloride (Prozac), with or without vitamins $A$ and $C$, in plant and animal model systems
}

\author{
E. Düsman ${ }^{1}$, I.V. Almeida ${ }^{1}$, R.G. Mariucci ${ }^{1}$, M.S. Mantovani ${ }^{2}$ and \\ V.E.P. Vicentini ${ }^{1}$ \\ ${ }^{1}$ Laboratório de Mutagênese e Monitoramento Animal, \\ Departamento de Biotecnologia, Genética e Biologia Celular, \\ Universidade Estadual de Maringá, Maringá, PR, Brasil \\ ${ }^{2}$ Departamento de Biologia Geral, Universidade Estadual de Londrina, \\ Londrina, PR, Brasil
}

Corresponding author: E. Düsman

E-mail: lisdusman@yahoo.com.br

Genet. Mol. Res. 13 (1): 578-589 (2014)

Received November 9, 2012

Accepted February 18, 2013

Published January 28, 2014

DOI http://dx.doi.org/10.4238/2014.January.28.3

\begin{abstract}
Fluoxetine, commonly known as Prozac, is the first representative of the so-called new generation of antidepressants that promise efficacy, with few side effects, against deep depression, nervous bulimia, and anxiety. As there is a growing number of people suffering from anxiety and depression; consequently, the use of fluoxetine is also increasing. Verifying absence of drug effects such as cytotoxicity or mutagenicity is of great importance. Certain vitamins, such as vitamin A (retinol, retinoids) and vitamin C (ascorbic acid) protect and are extremely active against mutagens. We evaluated the cytotoxic and mutagenic activity of fluoxetine, with and without concomitant administration of vitamin A or C, in Allium cepa meristem cells and Wistar rat bone marrow cells. The A. cepa meristem cells
\end{abstract}


showed fluoxetine cytotoxicity; concomitant treatment with vitamin A or $\mathrm{C}$ proved non-protective. Treatment of Wistar rats with fluoxetine intraperitoneally or via gavage did not affect cell division or cause clastogenic effects. Vitamin A and C did not affect the cytotoxicity or mutagenicity of fluoxetine in the rat cells.

Key words: Allium cepa; Antidepressant; Chromosomal alteration; Ascorbic acid; Retinol; Wistar rats

\section{INTRODUCTION}

Depression and anxiety disorders are common public health problems. Fluoxetine, commonly known as Prozac, is the first representative of the so-called new generation of antidepressants that promises high efficacy, with fewer side effects, against deep depression, nervous bulimic and anxiety (Le Pen et al., 1994; Hopkins, 1998). Its chemical name is (7)-Nmethyl-3-phenyl-3- ( $\alpha, \alpha, \alpha$-trifluoro-p-tolyloxy)propylamine hydrochloride, and it has the molecular formula $\mathrm{C}_{17} \mathrm{H}_{18} \mathrm{~F}_{3} \mathrm{NO} . \mathrm{HCl}$ (Figure 1). It consists of white crystals or a yellowish white powder and is soluble in water at a concentration of $14 \mathrm{mg} / \mathrm{mL}$ (Gracia, 1998).

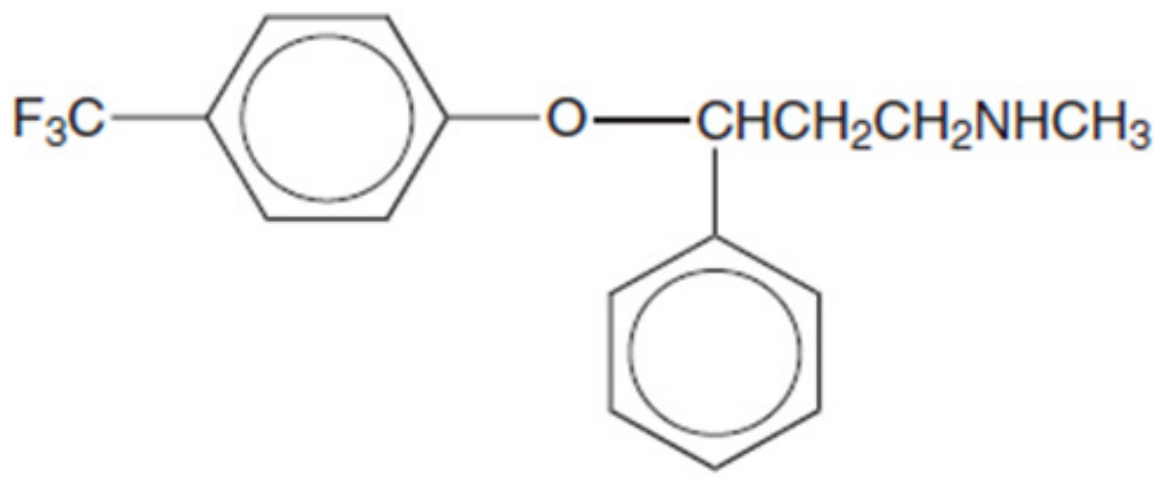

Figure 1. Chemical structure of fluoxetine (Source: Gracia, 2005).

Fluoxetine is a selective serotonin-reuptake inhibitor (SSRI); its target is serotonin, a neurotransmitter that acts as a messenger in cells of the central nervous system. SSRIs increase the serotonin concentration available in the brain and facilitate the transmission of information in nerve cells, ultimately relieving depression symptoms (Le Pen et al., 1994; Hopkins, 1998).

The therapeutic dose ranges from $20(64.7 \mu \mathrm{mol})$ to $60 \mathrm{mg} / \mathrm{day}$. The most commonly reported adverse effects are headache, nervousness, insomnia, drowsiness, tremor, nausea, anorexia and diarrhea. A decreased level of consciousness is the most common effect noted in overdose patients. Reported neurologic symptoms include tremor, confusion, ataxia, insomnia and coma. The most common cardiovascular effects include mild tachycardia, bradycardia and hypertension (Gracia, 1998).

Fluoxetine was introduced as an antidepressant and later rebranded for hormone replacement therapy to treat hot flashes in women with a history of breast cancer (Gracia, 2005). 
Krishnan et al. (2008) showed that fluoxetine is cytotoxic to tumor cell lines (human cervical cancer and breast cancer cells) and tumor-derived primary fibroblasts, inducing loss of viability mediated through apoptotic pathways. In another study, Kusakawa et al. (2008) proposed an association between an increase in major malformations by a mouse embryonic stem cell and the maternal use of SSRIs, such as fluoxetine, during pregnancy.

Ungvari et al. (1999) suggested that fluoxetine interferes with the $\mathrm{Ca}^{2+}$ signaling mechanisms in vascular smooth muscle. Cabrera-Vera and Battaglia (1998) suggested that prenatal exposure to fluoxetine produces site-specific and age-dependent alterations in serotonin transporters in the brains of rat progeny. Chronic treatment with fluoxetine causes functional supersensitivity in $5-\mathrm{HT}_{2}$ receptors that is mediated by $\mathrm{c}$-fos gene expression (Tilakaratne et al., 1995).

Simultaneous treatment with two chemical compounds may be employed to evaluate the effects of a mutagenic and a non-mutagenic compound on mammalian cells. Vitamins are largely used as antimutagenic agents. Vitamins A and C, among others, intercept the free radicals generated by cellular metabolism or exogenous sources, thus preventing attacks on lipids, proteins, the double bond of polyunsaturated fatty acids and bases of DNA. Preventing these attacks prevents injury and loss of cell integrity (Antunes and Bianchi, 1999) and protects humans against several types of mutations, cancers and diseases (Uenojo et al., 2007; Mozdarani and Ghoraeian, 2008).

Considering that most studies of fluoxetine have focused on its behavioral, physiological, psychological and neural effects, it is important to perform studies on fluoxetine's ability to induce DNA damage and cell cycle disruption in the entire body (e.g., bone marrow cells) not only in cells linked to the nervous system. Moreover, it is important to find ways to reduce these harmful effects, for example, through the combined use of antimutagenic substances. Thus, the possible mutagenic and cytotoxic activity of the antidepressant fluoxetine hydrochloride (Prozac), with and without the concomitant use of vitamin A or C, was evaluated in this work using two model systems: Allium cepa L. root meristem cells and Wistar rat bone marrow cells.

\section{MATERIAL AND METHODS}

\section{Treatment solutions}

Fluoxetine hydrochloride (Lilly, São Paulo, SP, Brazil) (FLU) was dissolved in water (20 mg pills) at concentrations of $0.02,0.04,0.08,0.20,0.40,0.50,0.80,1.00$, and $2.00 \mathrm{mg} / \mathrm{mL}$. The concentrations evaluated were chosen based on the recommended daily dose for human use.

Vitamin A (VA) Arovite (Roche, São Paulo, SP, Brazil) was diluted with water at a concentration of $0.8 \mathrm{mg} / \mathrm{mL}$. Vitamin C (VC) Redoxon (Roche) was diluted with water at a concentration of $0.3 \mathrm{mg} / \mathrm{mL}$.

Cyclophosphamide dissolved in water at a concentration of $1.5 \mathrm{mg} / \mathrm{mL}$ served as a positive control.

\section{A. cepa $\mathrm{L}$. root tip cells}

The experiment was conducted using the Feulgen reaction and Schiff's reagent for staining, according to the method originally introduced by Levan in 1949 (Fiskesjö, 1985). 
Onion bulbs were placed in bottles with water at room temperature and aerated in the dark for rooting. Before each treatment, three roots were collected and fixed ( 3 parts methanol:1 part acetic acid) to serve as its own control bulb (Co). Next, the roots of those bulbs were placed in treatment solutions: $0.5,1.0$ and $2.0 \mathrm{mg} / \mathrm{mL}$ FLU, $0.8 \mathrm{mg} / \mathrm{mL} \mathrm{VA,} 0.3 \mathrm{mg} / \mathrm{mL}$ $\mathrm{VC}, \mathrm{FLU}+\mathrm{VA}(2.0+0.8 \mathrm{mg} / \mathrm{mL})$ and FLU $+\mathrm{VC}(2.0+0.3 \mathrm{mg} / \mathrm{mL})$ for $24 \mathrm{~h}$. After the treatment period, three roots were withdrawn from each onion and fixed (Tr). The remaining roots were washed, and the bulbs were again placed in water for $24 \mathrm{~h}$ to recover from any damage; the remaining roots were then removed and fixed $(\mathrm{Re})$. The negative control onions remained in filtered water throughout the sampling time $\left(\mathrm{CO}^{-}\right)$.

The analysis of the slides was performed as blind tests using a light microscope with a 40X objective. To determine the mitotic index (MI), five bulbs were used for each treatment and control group: 1000 cells were analyzed per bulb, totalling 5000 cells per control, treatment, and recovery group.

Statistical analysis was performed using the chi-square test $(\mathrm{N}=5, \alpha=0.05)$.

\section{Wistar rat bone marrow cells}

Six Wistar rats, Rattus norvegicus, three males and three females for each group, were obtained from the Central Vivarium of Universidade Estadual de Maringá (UEM). Experiments were carried out using 35-day-old rats weighing approximately $100 \mathrm{~g}$ (b.w.). During the experimentation period, the animals remained under controlled temperature $\pm 25^{\circ} \mathrm{C}$ and humidity $\pm 50 \%$ and with a $12 \mathrm{~h}$ light/dark photoperiod, according to the standards established by the Ethics Committee on Experimentation with Laboratory Animals/UEM (process number PRO 520/2003).

\section{Acute treatment (intraperitoneal and gavage)}

Rats were treated in vivo with intraperitoneal injection (concentrations: 0.02, 0.04, $0.08,0.20,0.40,0.80$ and $2.0 \mathrm{mg} / \mathrm{mL})$ and by gavage $(0.5,1.0$ and $2.0 \mathrm{mg} / \mathrm{mL})$, for $24 \mathrm{~h}$, with $1 \mathrm{~mL}$ water or treatment solution/100 g b.w.

\section{Subchronic treatment (gavage)}

Wistar rats were submitted to a subchronic treatment for seven days. The control group received $1 \mathrm{~mL}$ water daily by gavage, and the treatment groups received the same quantity of treatment solutions at concentrations of $0.5,1.0$ and $2.0 \mathrm{mg} / \mathrm{mL}$. The rats were kept in cages with food and water changed daily at the same time, and on the eighth day, the rats were euthanized.

The chromosomal aberration test was performed in bone marrow cells of Wistar rats, using the method of Ford and Hamerton (1956) with some modifications. The mitotic cells were interrupted in metaphase with the intraperitoneal administration of $0.5 \mathrm{~mL} / 100 \mathrm{~g} \mathrm{~b}$.w. colchicine $(0.16 \%), 30 \mathrm{~min}$ before euthanasia. Analysis of the slides was performed using a light microscope by examining 100 metaphases per animal, totalling 600 for the control and treatment groups. The metaphases were checked for alterations including gaps, breaks, fragments and other chromosomal aberrations. The MI for cytotoxicity evaluation was calculated from 5000 cells per sex, totalling 10,000 cells per group. The MI calculation, as a percentage, was performed using the number of dividing cells divided by the total number of cells present in the fields. The statistical calculation was performed using the chi-square test $(\mathrm{N}=6, \alpha=0.05)$. 


\section{RESULTS}

\section{A. cepa L. root tip cells}

Figure 2 shows the mean MI (\%) obtained for the negative control group (CO-) and FLU $(0.50,1.0$ and $2.0 \mathrm{mg} / \mathrm{mL}), \mathrm{VA}(0.8 \mathrm{mg} / \mathrm{mL}), \mathrm{VC}(0.3 \mathrm{mg} / \mathrm{mL}), \mathrm{FLU}+\mathrm{VA}(2.0+0.8$ $\mathrm{mg} / \mathrm{mL})$, and FLU $+\mathrm{VC}(2.0+0.3 \mathrm{mg} / \mathrm{mL})$ treatment groups. All treatments $(24 \mathrm{~h})$ with FLU, with or without vitamins, and treatments with only vitamin A or C, decreased MI when compared to the control $(0 \mathrm{~h})$. However, the results were only statistically significant when compared to the corresponding sampling periods of negative control results $(\mathrm{MI} \mathrm{Tr}=10.3)$ in the following cases: the highest concentration of fluoxetine $\left(2.0 \mathrm{mg} / \mathrm{mL}, \mathrm{MI}=3.8, \chi^{2}=4.10\right.$, $\alpha=0.05)$, vitamin $\mathrm{A}\left(\mathrm{MI}=3.5, \chi^{2}=4.49, \alpha=0.05\right)$, vitamin $\mathrm{C}\left(\mathrm{MI}=4.0, \chi^{2}=3.85, \alpha=0.05\right)$, and fluoxetine plus vitamin $\mathrm{C}\left(\mathrm{MI}=3.0, \chi^{2}=5.17, \alpha=0.05\right)$. Recovery time $(\mathrm{Re})$ following treatment with the highest concentration of FLU $(2.0 \mathrm{mg} / \mathrm{mL}, \mathrm{MI}=2.5)$ was significantly different from the result for its own control $(0 \mathrm{~h})\left(\mathrm{MI}=8.4, \chi^{2}=4.14, \alpha=0.05\right)$ and the respective time for the negative control $(\mathrm{CO}-\mathrm{Re})\left(\mathrm{MI}=8.4, \chi^{2}=4.14, \alpha=0.05\right)$ by the chi-square test.

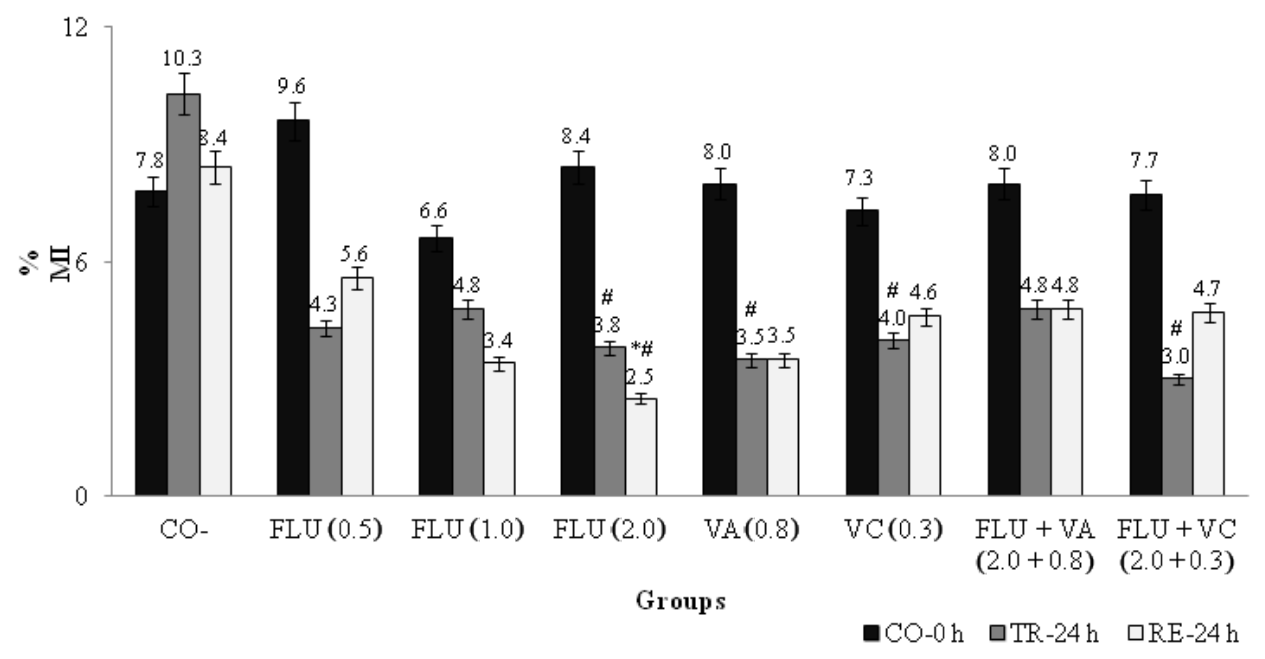

Figure 2. Mean percentage and standard deviation of mitotic index (MI) for the negative control group (CO-) and for cells treated $(\mathrm{mg} / \mathrm{mL})$ with fluoxetine (FLU), vitamin A (VA), vitamin C (VC), FLU + VA, and FLU + VC. Treatment time: Control $(\mathrm{CO})=0 \mathrm{~h}$, Treated $(\mathrm{TR})=24 \mathrm{~h}$, Recovery $(\mathrm{RE})=24 \mathrm{~h} .{ }^{*}$ Statistically significant result compared with corresponding control. \#Statistically significant result compared with corresponding time of negative control.

\section{Wistar rat bone marrow cells}

Figure 3 shows the mean MI and chromosomal alteration (CA) of acute intraperitoneal negative $(\mathrm{CO}-1, \mathrm{CO}-2)$ and positive $(\mathrm{CO}+)$ control groups and FLU-treated cells $(0.02$, $0.04,0.08,0.20,0.40,0.50,0.80,1.0$ and $2.0 \mathrm{mg} / \mathrm{mL}$ ). Statistical analysis showed that MIs and CAs for all concentrations of fluoxetine were not significantly different from their respective negative controls. 


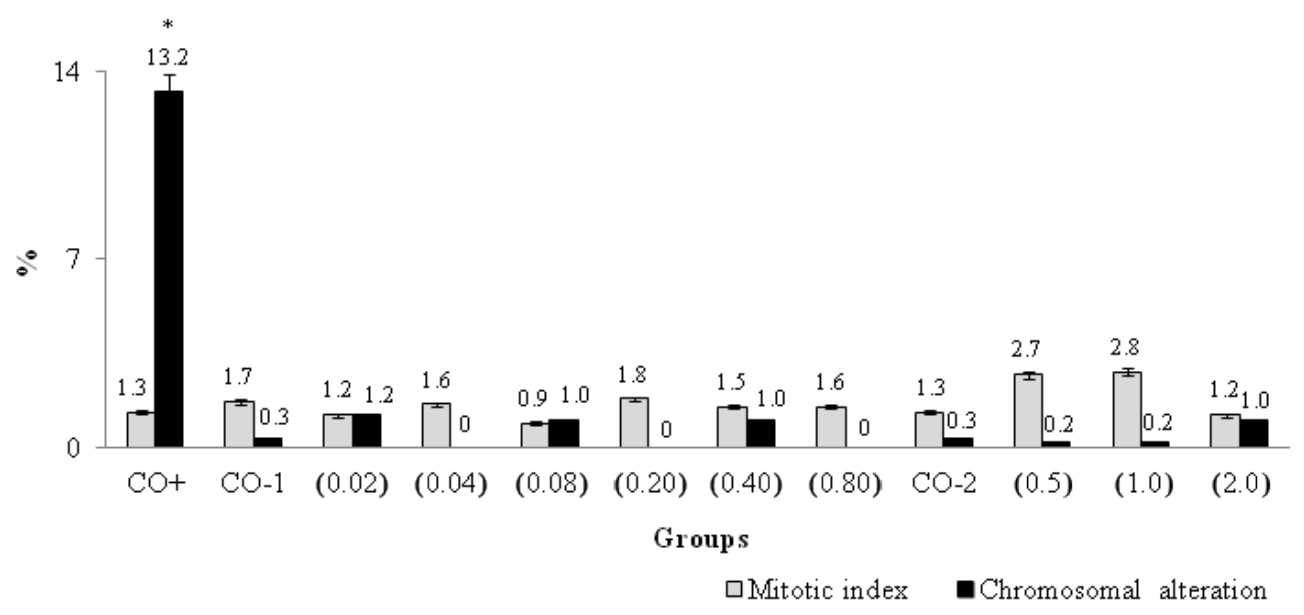

Figure 3. Mean percentage and standard deviation of mitotic index and chromosomal alteration of intraperitoneal acute treatment with negative $(\mathrm{CO}-1$ and $\mathrm{CO}-2)$ and positive $(\mathrm{CO}+)$ control groups and treatment with different concentrations of fluoxetine $(\mathrm{mg} / \mathrm{mL})$. *Statistically significant result compared with negative control.

Figure 4 shows the mean MI and CA for rats treated by gavage acutely and subchronically with different concentrations of FLU $(0.5,1.0$ and $2.0 \mathrm{mg} / \mathrm{mL})$ and for the negative and positive controls. Statistical analysis showed that MIs or CAs for all concentrations of fluoxetine were not significantly different from values of the respective negative controls.

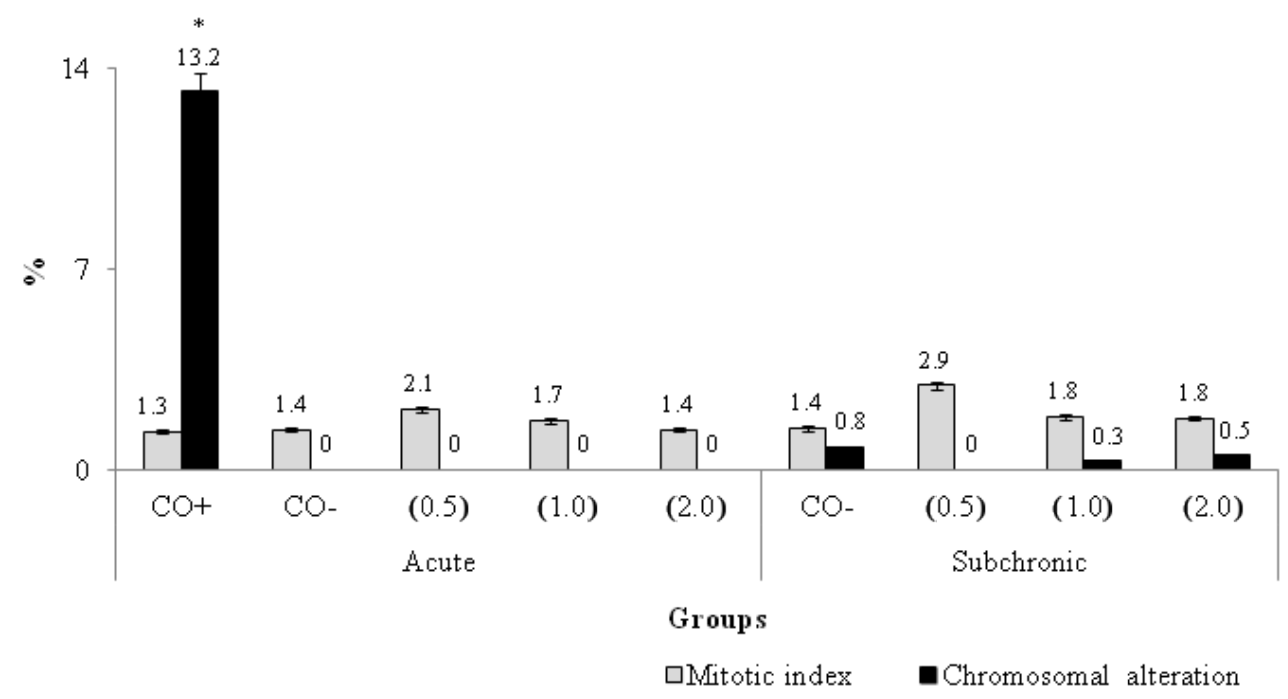

Figure 4. Mean percentage and standard deviation of mitotic index and chromosomal alteration with acute and subchronic gavage treatments with negative $(\mathrm{CO}-)$ and positive $(\mathrm{CO}+)$ control groups and treatment with different concentrations of fluoxetine $(\mathrm{mg} / \mathrm{mL})$. *Statistically significant result compared with negative control. 
Figure 5 shows the mean $\mathrm{MI}$ and $\mathrm{CA}$ of acute intraperitoneal negative and positive control groups, and FLU $(2.0 \mathrm{mg} / \mathrm{mL}), \mathrm{VA}(0.8 \mathrm{mg} / \mathrm{mL}), \mathrm{VC}(0.3 \mathrm{mg} / \mathrm{mL}), \mathrm{FLU}+\mathrm{VA}(2.0+$ $0.8 \mathrm{mg} / \mathrm{mL})$, and FLU + VC $(2.0+0.3 \mathrm{mg} / \mathrm{mL})$ treatment groups. Statistical analysis showed that neither fluoxetine nor vitamins $\mathrm{A}$ and $\mathrm{C}$ showed significantly different values relative to the negative or positive control with respect to MI. Regarding CAs, the results obtained for all treatments were significantly different from those obtained for the positive control group, but they were not significantly different from the results obtained for the negative control group.

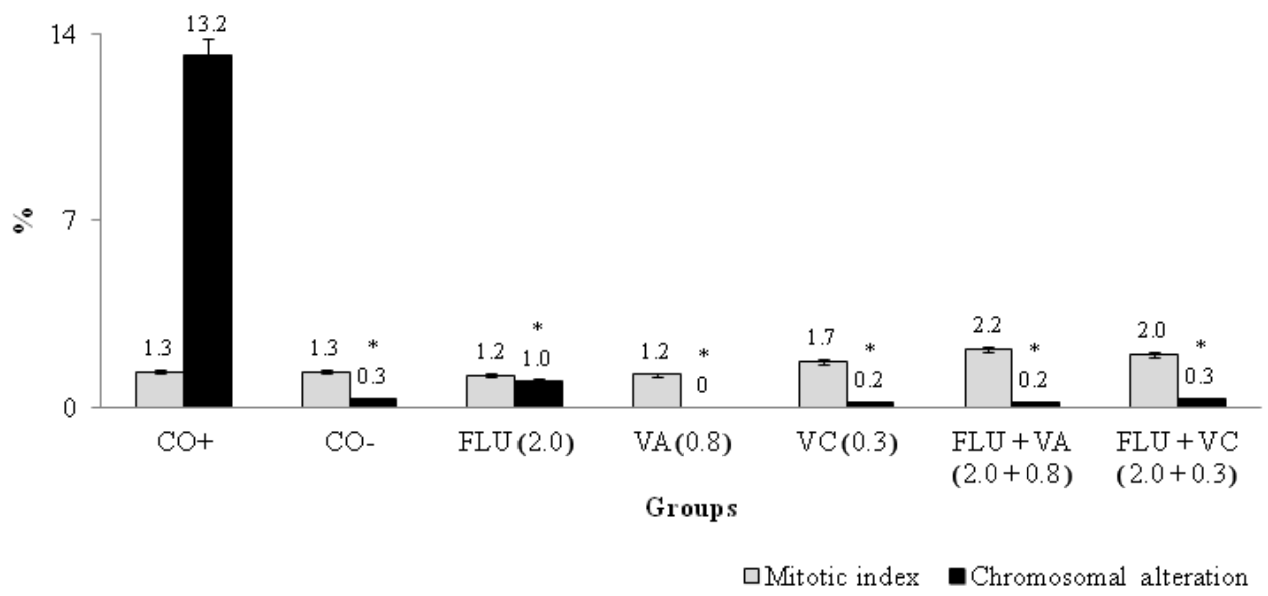

Figure 5. Mean percentage and standard deviation of mitotic index and chromosomal alteration of intraperitoneal acute treatment with negative $(\mathrm{CO}-)$ and positive $(\mathrm{CO}+)$ control groups and treatment $(\mathrm{mg} / \mathrm{mL})$ with fluoxetine (FLU), vitamin A (VA), vitamin C (VC), FLU + VA, and FLU + VC. *Statistically significant result compared with positive control.

Statistical analysis for all treatments (acute intraperitoneal and acute and subchronic gavage) showed that all concentrations of fluoxetine produced results that were different from the positive control with regard to CAs and MIs.

\section{DISCUSSION}

It is important to evaluate the cytotoxic potential and mutagenicity of compounds consumed by humans, particularly drugs. Fluoxetine, which is a popular antidepressant used for many years for the treatment of anxiety, depression and bulimia, was not cytotoxic or mutagenic in experiments with Wistar rats treated intraperitoneally for $24 \mathrm{~h}$ (acute form) (Figure 3 ), or via gavage for $24 \mathrm{~h}$ (acute form) or 7 days (subchronic form) (Figure 4). These results corroborate a compendium of reports of genotoxicity and carcinogenicity assays performed on marketed antidepressants, among them fluoxetine: a negative response in regard to genotoxicity assays (reverse mutation with Salmonella typhimurium, DNA repair synthesis with rat primary hepatocytes, gene mutation with mouse lymphoma L5178Y cells, and sister chromatid exchanges with bone marrow cells of Chinese hamster in vivo) and carcinogenicity assays in rodents (long-term carcinogenesis assays with B6C3F1 mice and Sprague-Dawley rats) and 
humans (breast cancer, ovarian cancer, colorectal cancer, cancer at other sites) (Brambilla et al., 2009, 2010, 2012).

Lemos et al. (2005) also showed that fluoxetine at concentrations of 0.2 and $1.0 \mathrm{mg} /$ $\mathrm{mL}$ was not genotoxic by the comet assay in Chinese hamster ovary $(\mathrm{CHO})$ cultured cells. However, they found fluoxetine was genotoxic at a concentration of $5.0 \mathrm{mg} / \mathrm{mL}$. These results were confirmed in the present study, as all concentrations tested, from the lowest $(0.02 \mathrm{mg} /$ $\mathrm{mL})$ to the highest $(2.0 \mathrm{mg} / \mathrm{mL})$, showed no mutagenic or cytotoxic potential in Wistar rats.

In contrast, Breton et al. (1999) showed the potential mutagenicity of 1.25, 2.5 and 5.0 $\mu \mathrm{g} / \mathrm{mL}$ fluoxetine in Chinese hamster V79 lung cells by the introduction of chromosomal breaks.

With respect to cytotoxic activity, the negative results in Wistar rats substantiate the work of Byrd and Markham (1994), which showed that orally administered fluoxetine at doses of 0.2 to $1.5 \mathrm{mg} / 100 \mathrm{~g}$ b.w. per day failed to show any toxicity with regard to cell growth in rat and rabbit embryos.

The lack of cytotoxicity of $2.0 \mathrm{mg}$ fluoxetine was confirmed by Vorhees et al. (1992, 1994), who also observed no cytotoxicity as demonstrated by functional deficiencies and behavioral abnormalities in pregnant rats treated with higher doses of this drug $(1.2 \mathrm{mg} / 100 \mathrm{~g} /$ day $)$. Similarly, fluoxetine in a dose range of 2 to $40 \mu \mathrm{M}$ was nontoxic to different cancer cell lines (human colon and breast carcinoma, murine leukemia, and highly aggressive mouse melanoma and Lewis lung carcinoma).

However, in another study, also using treatment by gavage and doses of 0.8 and 1.6 $\mathrm{mg} / 100 \mathrm{~g}$ of fluoxetine administered during the third week of pregnancy, confirmed toxicity with deleterious effects on prenatal growth. In contrast, in the present work, the administration of fluoxetine by gavage for 7 days did not show any cytotoxic effects on bone marrow cells of rats.

Nevertheless, various mammalian cell culture studies using different concentrations of fluoxetine have shown cytotoxic activity. For example, cytotoxic results were obtained using the tetrazolium salt reduction (MTT) assay to determine the inhibition of mitochondrial succinate dehydrogenase and the inhibition of neutral red uptake into lysosomes based on cell membrane damage in fish cell lines (Fent and Hunn, 1996; Caminada et al., 2006). Laville et al. (2004) found similar results determining the cytotoxicity of fluoxetine in PLHC-1 cells ( $5 \mu \mathrm{M}$ FLU) and primary cultures of rainbow trout hepatocytes ( $66 \mu \mathrm{M}$ FLU). Smith et al. (2012), also using rainbow trout liver microsomes treated with fluoxetine $(100 \mu \mathrm{M})$, showed that the drug was an in vitro inhibitor of mammalian cytochrome P450 enzymes.

Moreover, Thibaut and Porte (2008) also showed that fluoxetine exerted cytotoxic effects by decreasing the cell viability of a fish hepatoma cell line (PLHC-1) to 52\% after 24-h exposure to $20 \mu \mathrm{M}$ drug. Similarly, fluoxetine has been reported to inhibit ethoxyresorufin o-dealkylase activity in fish hepatocytes and liver microsomes (Laville et al., 2004). Lister et al. (2009) also demonstrated that $32 \mu \mathrm{g} / \mathrm{L}$ fluoxetine reduced gene expression of ovarian aromatase, follicle stimulating hormone receptor (FSHr) and luteinizing hormone receptor ( $\mathrm{LHr}$ ), levels of $17 \beta$-estradiol, and the average number of eggs spawned by mature female zebrafish. Souza et al. (1994) showed that fluoxetine influenced the energy metabolism of rat liver mitochondria and was potentially toxic at high doses. Kusakawa et al. (2008) showed the high toxicity of fluoxetine in mouse embryonic stem cells and NIH-3T3 fibroblasts by the MTT assay. In both cell lines, fluoxetine affected cell viability and differentiation from undifferentiated mouse embryonic stem cells to cardiomyocytes in a dose-dependent manner.

These results suggest that treatment of animals in vivo, similar to the method used in this work and at doses similar to those used in humans, allows further metabolism of the com- 
pounds followed by the removal, elimination or reduction of harmful cytotoxic metabolites of the drug fluoxetine. These processes typically do not occur in cell culture, especially if the experiments do not involve liver cells or the addition of metabolizing enzymes. Furthermore, in experiments conducted in cell culture, the compound comes into direct contact with the target cells tested, which may experience greater effects from the compound by having direct contact with the total concentration used. The data from the present study are important because they confirm the safe use of fluoxetine by humans.

In this sense, considering that $A$. cepa root cells remained in direct contact with the fluoxetine test solution, meristematic cells experienced the most direct action of this compound. Tests with A. cepa meristem cells showed a decrease in the rate of cell division in all treatments, but the difference was statistically significant only with the highest concentration of fluoxetine in relation to the negative control. This inhibition decreased significantly after the recovery time in water, showing significant results in relation to its own 0 hour control (Figure 2).

Moreover, the appearance of cytotoxic effects only at the highest dose of fluoxetine $(2.0 \mathrm{mg} / \mathrm{mL})$ in $A$. cepa might have been due to the exceedingly high concentrations tested. The concentrations chosen were calculated for body weight of Wistar rats $(100 \mathrm{~g})$ by extrapolating from the prescribed average human dosage of fluoxetine $(20 \mathrm{mg} /$ day $)$ multiplied by 20 , 40 and 80 times. Although these concentrations were not cytotoxic or mutagenic to rats, they might have been too high for onions, resulting in potential harm.

According to Rossetti et al. (2006), the cytotoxic effects of fluoxetine, as shown in several studies and in this work in the treatment of $A$. cepa with $2.0 \mathrm{mg} / \mathrm{mL}$ fluoxetine, may be because this type of drug affects the carrier's cells, thus resulting in cell death or the inhibition of cell division.

Moreover, vitamins $\mathrm{A}$ and $\mathrm{C}$ caused a significant decrease in cell division in relation to the negative control (Figure 2) and demonstrated cytotoxic activity in onion cells. When vitamins $A$ and $C$ were provided simultaneously with a concentration of $2.0 \mathrm{mg} / \mathrm{mL}$ fluoxetine, which alone had cytotoxic potential, only fluoxetine plus vitamin $C$ yielded a significantly different MI that was lower than that of the negative control after $24 \mathrm{~h}$ of treatment. Although both vitamin $\mathrm{A}$ and vitamin $\mathrm{C}$ are antioxidants, these vitamins display both pro-oxidant and pro-carcinogenic activities. At high concentrations, beta-carotene (pro-vitamin A) may have antagonistic activity, inducing oxidative stress by increasing free radicals and causing harmful changes in cells (Palozza, 2005; Gomes, 2007). Bhat et al. (2006) used human peripheral lymphocytes and the comet assay to show that ascorbic acid (100-200 mM) can cause oxidative damage to DNA in normal cells.

The results (Figure 5) showed that vitamins A $(0.8 \mathrm{mg} / \mathrm{mL})$ and $\mathrm{C}(0.3 \mathrm{mg} / \mathrm{mL})$ were neither cytotoxic nor mutagenic in the acute treatment with intraperitoneal administration. These results corroborate the work of Lemos et al. (2005) who showed no genotoxic effects of vitamin A $(3.0 \mathrm{mg} / \mathrm{mL})$ or vitamin $\mathrm{C}(880.5 \mathrm{mg} / \mathrm{mL})$ by the comet assay in $\mathrm{CHO}$ cells. The results presented here for fluoxetine treatment via gavage are in line with an earlier reported study showing that vitamin C, administered orally at doses of $100,200,400$ and $800 \mathrm{mg} / \mathrm{kg}$ b.w., did not increase the frequency of chromosome aberrations in bone marrow cells of rats (Ghaskadbi and Vaidya, 1989). The negative results for the MI were similar to those obtained by Nefic (2001), who observed that vitamin C (10 and $100 \mu \mathrm{g} / \mathrm{mL})$ did not alter the MI of human peripheral lymphocytes treated in vitro. Kumari and Sinha (1994) showed that treat- 
ment of albino Swiss mice with vitamin A at $132 \mathrm{IU} / \mathrm{kg}$ b.w. per day, administered orally, had no genotoxicity according to the examination of mitotically dividing bone marrow cells and sperm-head morphology.

Vitamins $\mathrm{A}$ and $\mathrm{C}$ are active protective factors against known in vivo and in vitro mutagenic compounds. However, we could not demonstrate the protective effect of these vitamins using rat cells (Figure 5), mainly because fluoxetine was not cytotoxic or mutagenic as shown by the chromosome aberration test with rat bone marrow cells. However, in the presence of the mutagenic fluoxetine, studies using other model systems have demonstrated the protective effect of these vitamins. For example, Breton et al. (1999) showed that vitamin A ( $41 \times 10^{3} \mu \mathrm{g} / \mathrm{mL}$ ) protected CHO cells from chromosomal breaks induced by $5.0 \mu \mathrm{g} / \mathrm{mL}$ fluoxetine, and vitamin $\mathrm{C}\left(66.6 \times 10^{3} \mu \mathrm{g} / \mathrm{mL}\right)$ protected cells from the toxic effects of $1.25,2.5$ and $5.0 \mu \mathrm{g} / \mathrm{mL}$ fluoxetine. Furthermore, vitamins A $(3.0 \mathrm{mg} / \mathrm{mL})$ and C $(880.5 \mathrm{mg} / \mathrm{mL})$ decreased the genotoxicity of fluoxetine $(5.0 \mathrm{mg} / \mathrm{mL})$ as shown by the comet assay in $\mathrm{CHO}$ cell cultures (Lemos et al., 2005). Moreover, reduced glutathione and vitamin E decreased the toxicity of both fluoxetine and paroxetine. According to the authors, reduced glutathione reacts with electrophilic metabolites and detoxifies them, reacts with $\mathrm{H}_{2} \mathrm{O}_{2}$ and fatty acid peroxides, and maintains the optimal redox state of the cell, thereby preventing oxidative stress-induced cell death. Vitamin E protects cell membranes against lipid peroxidation and provides cytoprotection against the mitochondria-derived oxidative stress induced by alkylating agents (Meister, 1991; Bains and Shaw, 1997; Tirmenstein et al., 2000; Zhang et al., 2001).

The findings of this study indicate that fluoxetine with or without concomitant vitamin A or C treatment was only cytotoxic to $A$. cepa cells. Wistar rats treated intraperitoneally or by gavage demonstrated no cytotoxic or mutagenic potential of the drug. Thus, the results suggest that the use of fluoxetine in humans is safe, since the mammalian model is more representative of human consumption than is the plant model.

This work is important because it shows that fluoxetine does not cause DNA damage of cells of metabolic organisms and that fluoxetine, although previously reported to be toxic, is not toxic to rats. Additionally, these data were obtained by the evaluation of cytotoxicity and chromosome aberrations in bone marrow cells of Wistar rats; both the cell type and the method differ from those previously used. There are a growing number of people suffering from anxiety and depression, therefore increasing the need for fluoxetine. Thus, verifying the absence of effects such as cytotoxicity or mutagenicity is of great importance.

\section{ACKNOWLEDGMENTS}

The authors thank Esp. Rosinete Gonçalves Mariucci for her technical assistance.

\section{REFERENCES}

Antunes LMG and Bianchi MLP (1999). Radicais livres e os principais antioxidantes da dieta. Rev. Nutr. 12: 123-130.

Bains JS and Shaw CA (1997). Neurodegenerative disorders in humans: the role of glutathione in oxidative stress-mediated neuronal death. Brain Res. Rev. 25: 335-358.

Bhat SH, Azmi AS, Hanif S and Hadi SM (2006). Ascorbic acid mobilizes endogenous copper in human peripheral lymphocytes leading to oxidative DNA breakage: a putative mechanism for anticancer properties. Int. J. Biochem. Cell Biol. 38: 2074-2081.

Brambilla G, Mattioli F and Martelli A (2009). Genotoxic and carcinogenic effects of antipsychotics and antidepressants. Toxicology 261: 77-88. 
Brambilla G, Mattioli F, Robbiano L and Martelli A (2010). Genotoxicity and carcinogenicity testing of pharmaceuticals: correlations between induction of DNA lesions and carcinogenic activity. Mutat. Res. 705: 20-39.

Brambilla G, Mattioli F, Robbiano L and Martelli A (2012). Update of carcinogenicity studies in animals and humans of 535 marketed pharmaceuticals. Mutat. Res. 750: 1-51.

Breton MC, Vicentini VEP and Mantovani MS (1999). Clastogenicidade do medicamento Prozac em cultura de células de mamíferos. Genet. Mol. Biol. 22: 45.

Byrd RA and Markham JK (1994). Developmental toxicology studies of fluoxetine hydrochloride administered orally to rats and rabbits. Fundam. Appl. Toxicol. 22: 511-518.

Cabrera-Vera TM and Battaglia G (1998). Prenatal exposure to fluoxetine (Prozac) produces site-specific and agedependent alterations in brain serotonin transporters in rat progeny: evidence from autoradiographic studies. $J$. Pharmacol. Exp. Ther. 286: 1474-1481.

Caminada D, Escher C and Fent K (2006). Cytotoxicity of pharmaceuticals found in aquatic systems: comparison of PLHC-1 and RTG-2 fish cell lines. Aquat. Toxicol. 79: 114-123.

Fent K and Hunn J (1996). Cytotoxicity of organic environmental chemicals to fish liver cells (PLHC-1). Mar. Environ. Res. 42: 377-382.

Fiskesjö G (1985). The Allium test as a standard in environmental monitoring. Hereditas 102: 99-112.

Ford CE and Hamerton JL (1956). A colchicine, hypotonic citrate, squash sequence for mammalian chromosomes. Stain Technol. 31: 247-251.

Ghaskadbi S and Vaidya VG (1989). In vivo antimutagenic effect of ascorbic acid against mutagenicity of the common antiamebic drug diiodohydroxyquinoline. Mutat. Res. 222: 219-222.

Gomes FS (2007). Carotenóides: uma possível proteção contra o desenvolvimento do câncer. Rev. Nutr. 20: 537-548.

Gracia R (2005). Fluoxetine. In: Douglas J Borys, Elsevier Inc., Philadelphia, 2: 7-8.

Hopkins J (1998). Health after 50. Depression: Benefiting from treatment advances. Med. Lett. 10: 04-05.

Krishnan A, Hariharan R, Nair SA and Pillai MR (2008). Fluoxetine mediates G0/G1 arrest by inducing functional inhibition of cyclin dependent kinase subunit (CKS)1. Biochem. Pharmacol. 75: 1924-1934.

Kumari D and Sinha SP (1994). Effect of retinol on ochratoxin-produced genotoxicity in mice. Food Chem. Toxicol. 32: 471-475.

Kusakawa S, Yamauchi J, Miyamoto Y, Sanbe A, et al. (2008). Estimation of embryotoxic effect of fluoxetine using embryonic stem cell differentiation system. Life Sci. 83: 871-877.

Laville N, Ait-Aissa S, Gomez E, Casellas C, et al. (2004). Effects of human pharmaceuticals on cytotoxicity, EROD activity and ROS production in fish hepatocytes. Toxicology 196: 41-55.

Le Pen C, Levy E, Ravily V, Beuzen JN, et al. (1994). The cost of treatment dropout in depression. A cost-benefit analysis of fluoxetine vs. tricyclics. J. Affect. Disord. 31: 1-18.

Lemos NG, Vicentini VEP and Mantovani MS (2005). Avaliação do efeito genotóxico do Prozac (fluoxetina), sem e com adição de vitaminas A e C, através do teste do cometa em cultura de células CHO-K1. Semina Ciênc. Biol. Saúde 26: $95-100$.

Lister A, Regan C, Van ZJ and Van Der Kraak G (2009). Inhibition of egg production in zebrafish by fluoxetine and municipal effluents: a mechanistic evaluation. Aquat. Toxicol. 95: 320-329.

Meister A (1991). Glutathione deficiency produced by inhibition of its synthesis, and its reversal; applications in research and therapy. Pharmacol. Ther. 51: 155-194.

Mozdarani H and Ghoraeian P (2008). Modulation of gamma-ray-induced apoptosis in human peripheral blood leukocytes by famotidine and vitamin C. Mutat. Res. 649: 71-78.

Nefic H (2001). Anticlastogenic effect of vitamin C on cisplatin induced chromosome aberrations in human lymphocyte cultures. Mutat. Res. 498: 89-98.

Palozza P (2005). Can beta-carotene regulate cell growth by a redox mechanism? An answer from cultured cells. Biochim. Biophys. Acta 1740: 215-221.

Rosetti M, Frasnelli M, Tesei A, Zoli W, et al. (2006). Cytotoxicity of different selective serotonin reuptake inhibitors (SSRIs) against cancer cells. J. Exp. Ther. Oncol. 6: 23-29.

Smith EM, Iftikar FI, Higgins S, Irshad A, et al. (2012). In vitro inhibition of cytochrome P450-mediated reactions by gemfibrozil, erythromycin, ciprofloxacin and fluoxetine in fish liver microsomes. Aquat. Toxicol. 109: 259-266.

Souza ME, Polizello AC, Uyemura SA, Castro-Silva O, et al. (1994). Effect of fluoxetine on rat liver mitochondria. Biochem. Pharmacol. 48: 535-541.

Thibaut R and Porte C (2008). Effects of fibrates, anti-inflammatory drugs and antidepressants in the fish hepatoma cell line PLHC-1: cytotoxicity and interactions with cytochrome P450 1A. Toxicol. In Vitro 22: 1128-1135.

Tilakaratne N, Yang ZL and Friedman E (1995). Chronic fluoxetine or desmethylimipramine treatment alters 5-HT2 receptor mediated c-fos gene expression. Eur. J. Pharmacol. 290: 263-266. 
Tirmenstein MA, Nicholls-Grzemski FA, Schmittgen TD, Zakrajsek BA, et al. (2000). Glutathione-dependent regulation of nitric oxide production in isolated rat hepatocyte suspensions. Antioxid. Redox. Signal. 2: 767-777.

Uenojo M, Maróstica-Junior MR and Pastore GM (2007). Carotenóides: Propriedades, aplicações e biotransformação para formação de compostos de aroma. Quím. Nova 30: 616-622.

Ungvari Z, Pacher P, Kecskemeti V and Koller A (1999). Fluoxetine dilates isolated small cerebral arteries of rats and attenuates constrictions to serotonin, norepinephrine, and a voltage-dependent $\mathrm{Ca}^{2+}$ channel opener. Stroke 30: 19491954.

Vorhees CV, Acuff-Smith KD, Schilling MA and Fisher JE (1992). Evaluation of the behavioral teratogenic potential of fluoxetine in rats. Teratology 45: 526-527.

Vorhees CV, Acuff-Smith KD, Schilling MA, Fisher JE, et al. (1994). A developmental neurotoxicity evaluation of the effects of prenatal exposure to fluoxetine in rats. Fundam. Appl. Toxicol. 23: 194-205.

Zhang JG, Nicholls-Grzemski FA, Tirmenstein MA and Fariss MW (2001). Vitamin E succinate protects hepatocytes against the toxic effect of reactive oxygen species generated at mitochondrial complexes I and III by alkylating agents. Chem. Biol. Interact. 138: 267-284. 